\title{
Sensory nerve conduction in the caudal nerves of rats with diabetes ${ }^{1}$
}

\section{Condução nervosa sensorial no nervo caudal de ratos com diabetes experimental}

\author{
Celina Cordeiro de CarvalhoI, Juliana Netto Maia ${ }^{\text {II }}$, Otávio Gomes Lins ${ }^{\text {III }}$, Sílvia Regina Arruda de Moraes ${ }^{\text {IV }}$ \\ ${ }^{1}$ Research performed at the Department of Anatomy Laboratory, Center of Biological Sciences, Postgraduate Program in Neuropsychiatry and \\ Behavioural Sciences, Federal University of Pernambuco (UFPE), Brazil. Part of a PhD degree thesis. Tutor: Sílvia Regina Arruda de Moraes.

\begin{abstract}
${ }^{\mathrm{I}}$ Fellow PhD degree, Postgraduate Program in Neuropsychiatry and Behavioural Sciences, UFPE, Recife-PE, Brazil. Main author, responsible for the intellectual and scientific content of the article, acquisition, analysis and interpretation of data.

${ }^{\text {II }}$ Fellow PhD degree, Postgraduate Program in Neuropsychiatry and Behavioural Sciences, UFPE, Recife-PE, Brazil. Intellectual and scientific content of the article and acquisition of data.

III PhD, Associate Professor, Department of Neuropsychiatry, UFPE, Recife-PE, Brazil. Responsible for the electrophysiologycal supervision, critically revising the article and statistical analysis.

Iv PhD, Associate Professor, Department of Anatomy, UFPE, Recife-PE, Brazil. Tutor, responsible for design, for important intellectual content of the
\end{abstract} \\ article and final approval of the version to be published.
}

\begin{abstract}
Purpose: To investigate sensory nerve conduction of the caudal nerve in normal and diabetic rats. Methods: Diabetes was induced in twenty 8-weeks old Wistar male rats. Twenty normal rats served as controls. Caudal nerve conduction studies were made before diabetes induction and the end of each week for six consecutive weeks. The caudal nerve was stimulated distally and nerve potentials were recorded proximally on the animal's tail using common "alligator" clips as surface electrodes. Results: After induction, nerve conduction velocities (NCV) increased slower in the diabetic than in the control group. Sensory nerve action potentials (SNAP) conduction velocities increased slower in the diabetic than in the control group (slope of regression line: $0.5 \mathrm{vs} 1.3 \mathrm{~m} / \mathrm{s}$ per week; NCV in the $15^{\text {th }}$ week $=39 \pm 3 \mathrm{~m} / \mathrm{s}$ vs $44 \pm 4 \mathrm{~m} / \mathrm{s}$ ). Tukey's tests showed differences between groups at the $11^{\text {th }}, 13^{\text {th }}$ and $15^{\text {th }}$ weeks old. From the $10^{\text {th }}$ week on, SNAP amplitudes increased faster in the diabetic than in the control group (slopes of the regression line: $10 v s 8 \mu \mathrm{V}$ per week; SNAP amplitudes in the $15^{\text {th }}$ week: $\left.107 \pm 23 \mu \mathrm{V} v s 85 \pm 13 \mu \mathrm{V}\right)$. Differences at the $12^{\text {th }}, 13^{\text {th }}$ and $15^{\text {th }}$ weeks were significant. Conclusion: In diabetic rats nerve conduction velocities were slower whereas amplitudes were larger than in normal rats.

Key words: Diabetes Mellitus, Experimental. Neural Conduction. Tail. Rats.

\section{RESUMO}

Objetivo: Investigar a condução nervosa sensorial do nervo caudal em ratos normais e diabéticos. Métodos: O diabetes foi induzido em vinte ratos Wistar com idade de oito semanas. Vinte ratos serviram como controle. Os estudos da condução do nervo caudal foram feitos antes da indução do diabetes e ao final de cada semana, durante seis semanas consecutivas. O nervo caudal foi estimulado distalmente e potenciais foram registrados proximalmente na cauda do animal, usando clipes comuns "jacaré" como eletrodos de superfície. Resultados: Após a indução, a velocidade de condução nervosa (VCN) aumentou mais lentamente no grupo diabético que no controle. Potenciais de ação dos nervos sensitivos (PANS) aumentaram a velocidade de condução mais lentamente no grupo diabético que no controle (linha de regressão: $0,5 v s 1,3 \mathrm{~m} / \mathrm{s}$ por semana; VCN na $15^{\mathrm{a}}$ semana $=39 \pm 3 \mathrm{~m} / \mathrm{s} v s 44 \pm 4 \mathrm{~m} / \mathrm{s}$ ). O teste de Tukey mostrou diferenças entre os grupos nas $11^{\mathrm{a}}, 13^{\mathrm{a}}$ e $15^{\mathrm{a}}$ semanas de vida. A partir da semana 10, os PANS aumentaram mais rapidamente no grupo diabético que no controle (linha de regressão: $10 v s 8 \mu \mathrm{V}$ por semana; PANS na $15^{\mathrm{a}}$ semana: $107 \pm 23 \mu \mathrm{V} v s 85 \pm 13 \mu \mathrm{V}$ ). Diferenças na semana 12, 13 e 15 foram significativas. Conclusão: Nos ratos diabéticos a velocidade de condução nervosa foi mais lenta enquanto que as amplitudes foram maiores que em ratos normais.
\end{abstract}

Descritores: Diabetes Mellitus Experimental. Condução Nervosa. Cauda. Ratos. 


\section{Introduction}

Peripheral polyneuropathy is a common complication of diabetes mellitus ${ }^{1}$. It consists of demyelization and axonal degeneration of peripheral nerves ${ }^{1}$, leading to slowing of nerve conduction velocity and reduction of the amplitude of the compound muscle and sensory nerve action potentials ${ }^{1-8}$. These features of diabetic polyneuropathy are observed in humans diabetes ${ }^{1,9}$ and experimentally induced diabetes in animals ${ }^{2-8}$.

Along with the sciatic, fibular, tibial, sural, saphenous, and facial nerves $3,6,10,11$, the caudal nerve has often been used for electrophysiological studies in rats $^{2,4,5,12}$, because the long tail allows accurate measurement of distances and the small diameter of the tail facilitates the placement of the stimulating and recording electrodes close to the nerve ${ }^{12,13}$. Most animal nerve conduction studies use invasive techniques, with needle electrodes ${ }^{2-6,12,14,15}$ or surgical access to the nerve ${ }^{10,11}$. A smaller number of studies use non-invasive techniques, with surface electrodes ${ }^{16-18}$.

The objective of this work was to investigate sensory nerve conduction of the caudal nerve in normal and diabetic rats.

\section{Methods}

Forty Wistar rats were used (Rattus norvegicus), male albino rats with 8-weeks old, from the Nutrition Department Animal Lab Center of the Federal University of Pernambuco. Animals were kept in collective plastic cages (maximum of 5 animals/cage), under a temperature of $23 \pm 1^{\circ} \mathrm{C}$, an inverted $12 \mathrm{~h}$ day/night cycle, with free access to water and food (Labina). Animals were randomly divided in two groups of 20 animals: The Control Group, diabetes free and the Diabetes Group, with nontreated experimentally induced diabetes. Diabetes was induced by a single intraperitoneal injection of $60 \mathrm{mg} / \mathrm{kg}$ streptozotocin (Sigma Chemical Co., USA) diluted in buffer solution (sodium citrate, $10 \mathrm{mM}, \mathrm{pH} 4.5$ ) after 12 hours of fasting ${ }^{23}$. Animals in the control group received the same buffer solution without streptozotocin. After 30 minutes both groups were fed normally. Blood glucose was measured 3 and 7 days after induction, with blood samples collected from the tip of the tail after 12 hours of fasting. Only animals with blood glucose above $200 \mathrm{mg} / \mathrm{dL}$ (Glucosymmetry AccuCheck - Roche) were admitted in the Diabetes Group. Both groups received a weekly blood glucose check up.

Methods applied to handle and care for animals are in accordance with the National Institute of Health Guide for Care and Use of Laboratory Animal standards and were approved by the Ethics Committee for Animal Experimentation of the Federal University of Pernambuco.

\section{Electrophysiology}

Caudal nerve conduction studies were made before diabetes induction and the end of each week for six consecutive weeks. After anesthesia with a intramuscular injection of a mixture of Xylazin Chlorhydrate (Rompum) and Ketamin (Ketalar), $0.2 \mathrm{ml} / 100 \mathrm{~g}^{19}$, animals were positioned ventrally for their tail to be completely loose and the tail was clean and fat free with alcohol at $70 \%$.
An orthodromic technique was used ${ }^{19}$ : The caudal nerve was stimulated distally (duration: $0.1 \mathrm{~ms}$; intensity: $10-20 \mu \mathrm{A}$, supramaximal) and the sensory nerve action potentials (SNAP's) were recorded proximally (high-pass filter: $10 \mathrm{~Hz}$; low-pass filter: $10 \mathrm{kHz}$ ) on the animal's tail. No movement of the tail was noted during stimulation. A Racia-Alvar Centor electromyograph was used. The SNAP parameters studied were peak-to-peak amplitude $(\mu \mathrm{V})$ and nerve conduction velocity $(\mathrm{m} / \mathrm{s})$, derived from the onset latency (ms). Measurements were taken 4 times and the accepted result was their arithmetic average. Stimulation, recording and ground electrodes were identical standard "alligator" clips ${ }^{19}$. The distance between the stimulating cathode and the non-inverting recording electrode was $8 \mathrm{~cm}$, whereas the distance between the pair of stimulating and recording electrodes was $3 \mathrm{~cm}$. The ground was connected to the pair of alligator clips located between the stimulation and recording electrodes. The springs of the alligator clips were removed to prevent excessive compression of the tail.

Due to the almost linear relationship between the temperature of the tail and the nerve conduction velocity ${ }^{20}$, before each recording the temperature of the tail was maintained at $31-32^{\circ} \mathrm{C}$ and confirmed before each recording with an infrared thermometer (Doc Thermo; Comdek Industrial Corp.). A dichroic lamp was used for heating.

\section{Statistical analysis}

Data were summarized by mean and standard deviation. The statistical significance of the differences was tested with mixedmodel analysis of variance (ANOVA). Post-hoc comparisons were made by Tukey test. The critical $p$ for both tests was 0.05 .

\section{Results}

After two weeks of the induction period the animals in the experimental group showed increased levels of blood glucose, whereas those in the control group had normal glucose levels (Table 1).

TABLE 1 - Mean (standard deviation) of blood glucose levels (mg/100ml) by age (weeks) of diabetic and control rats

\begin{tabular}{l|ccccccc}
\hline Age (Weeks) & $\mathbf{8}$ & $\mathbf{1 0}$ & $\mathbf{1 1}$ & $\mathbf{1 2}$ & $\mathbf{1 3}$ & $\mathbf{1 4}$ & $\mathbf{1 5}$ \\
\hline Diabetics & $83 \pm 10$ & $251 \pm 111$ & $249 \pm 129$ & $251 \pm 121$ & $349 \pm 151$ & $314 \pm 109$ & $324 \pm 101$ \\
Controls & $79 \pm 9$ & $78 \pm 21$ & $76 \pm 14$ & $80 \pm 8$ & $81 \pm 16$ & $79 \pm 12$ & $68 \pm 10$ \\
\hline
\end{tabular}

SNAP conduction velocities of diabetic and control animals are shown in Figure 1. There was no significant difference between them at eight weeks of life (pre-induction): $36 \pm 2 \mathrm{~m} / \mathrm{s}$ versus $34 \pm 3 \mathrm{~m} / \mathrm{s}$, respectively. After induction, SNAP conduction velocities increased slower in the diabetic than in the control group (slope of regression line: 0.5 versus $1.3 \mathrm{~m} / \mathrm{s}$ per week; NCV in the $15^{\text {th }}$ week $=39 \pm 3 \mathrm{~m} / \mathrm{s}$ versus $44 \pm 4 \mathrm{~m} / \mathrm{s}$ ). Post hoc tests (Tukey) showed significant differences between groups at the $11^{\text {th }}, 13^{\text {th }}$ and $15^{\text {th }}$ weeks. 


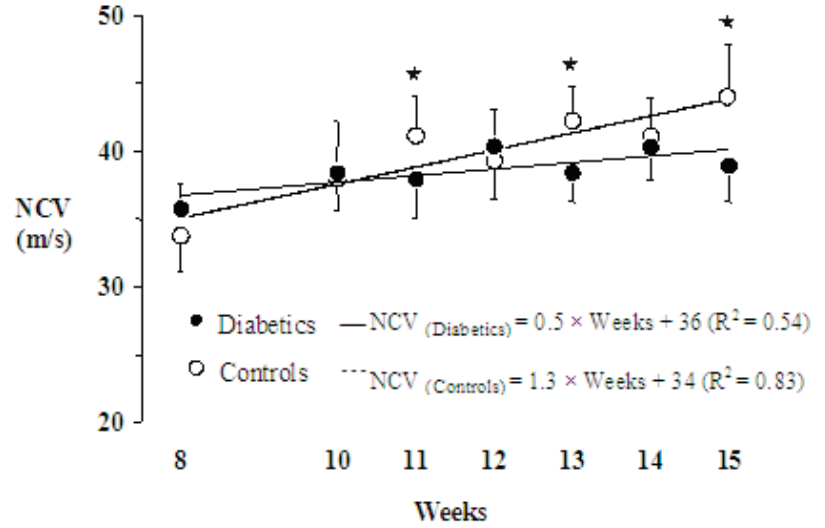

FIGURE 1 - Mean (standard deviation) of conduction velocities $(\mathrm{m} / \mathrm{s})$ by age (weeks) of diabetic (filled circles) and control (open circles) rats. Linear regression equations and square of Pearson correlation coefficient $\left(\mathrm{R}^{2}\right)$.

$>$ Tukey, $\mathrm{p}<0.05$; diabetics rats versus controls rats.

Figure 2 shows SNAP amplitudes of diabetic and control animals. At the $8^{\text {th }}$ week (pre-induction; baseline) the SNAP amplitudes were not different between the two groups $(33 \pm 7 \mu \mathrm{V}$ versus $29 \pm 6 \mu \mathrm{V})$. From the $10^{\text {th }}$ week, SNAP amplitudes increased faster in the diabetic than in the control group (slopes of the regression line: 10 versus $8 \mu \mathrm{V}$ per week; SNAP amplitudes in the $15^{\text {th }}$ week: $107 \pm 23 \mu \mathrm{V}$ versus $\left.85 \pm 13 \mu \mathrm{V}\right)$. Differences at the $12^{\text {th }}$, $13^{\text {th }}$ and $15^{\text {th }}$ weeks were statistically significant (Tukey).

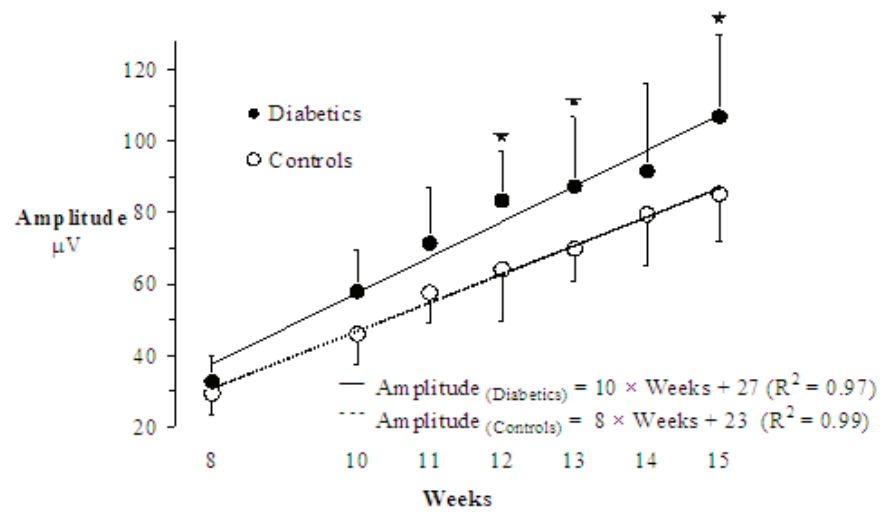

FIGURE 2 - Mean (standard deviation) of amplitudes $(\mu \mathrm{V})$ by age (weeks) of diabetic (filled circles) and control (open circles) rats. Linear regression equations and square of Pearson correlation coefficient $\left(\mathrm{R}^{2}\right)$.

$>$ Tukey, $\mathrm{p}<0.05$; diabetics rats versus controls rats.

Rats with diabetes lost weight during the experiment, whereas those in the control group gained weight (Figure 3). In the $15^{\text {th }}$ week, the average weight of the diabetic rats was about $40 \%$ lower than the weights of the control rats.

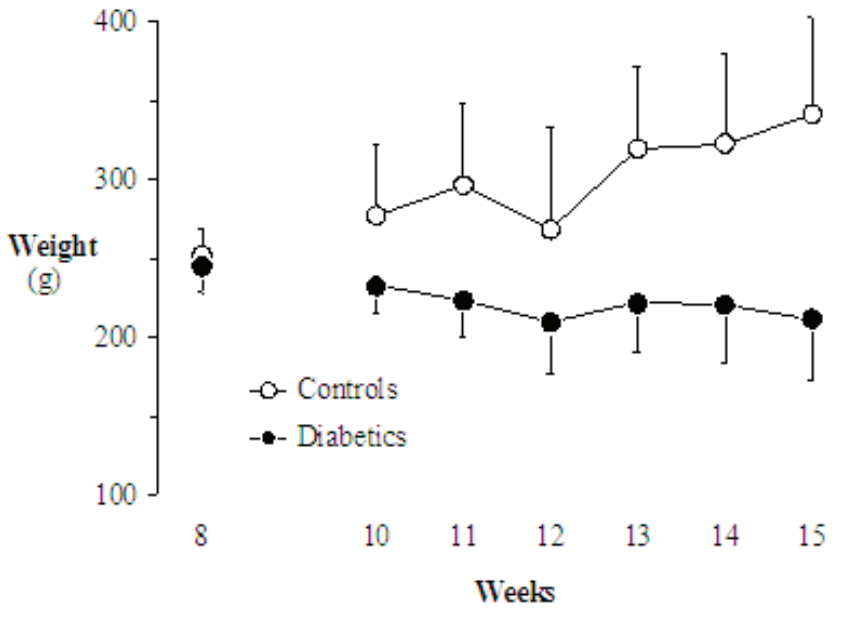

FIGURE 3 - Mean (standard deviation) of the weight (g) by age (weeks) of diabetic (filled circles) and control (open circles) rats.

\section{Discussion}

The rat caudal nerve has good characteristics for studying nerve conduction using non-invasive techniques. Its superficial trajectory allows easy stimulation and recording of potentials with surface electrodes ${ }^{21}$ and its long trajectory $(10-15 \mathrm{~cm})$ allows accurate measurement of distances ${ }^{18}$.

In our data SNAP conduction velocities increased slower with age in the diabetic rats than in the normal rats. This was an expected result. Several authors obtained similar results studying the caudal nerve $\mathrm{e}^{2,4,5,20}$ or other nerves ${ }^{3,6,7}$. The slower conduction velocity is probably due to an abnormal development of the myelin sheath in the peripheral nerves of the diabetic rats.

Caudal nerve SNAP amplitudes increased faster in the diabetic rats than in the normal rats. This was an unexpected result. We expected a decrease in the rate of growth of the SNAP amplitude in the diabetic rats, due to the axonal loss and temporal dispersion of SNAP related to the diabetic polyneuropathy. Zochodne and Nguyen $^{22}$ reported larger caudal nerve SNAP amplitudes in diabetic rats compared to non-diabetic rats. However, they did not discuss this result nor state if this difference was statistically significant.

The higher amplitude of the SNAP in the diabetic rats could be caused by a lower temperature of the animal's tail. Low temperature is known to cause SNAP amplitude to increase and nerve conduction velocity to fall ${ }^{20}$. However, we monitored the temperature of the tail and kept it fairly constant.

Most probably the reason for this finding was the smaller development of the tail diameter in the diabetic rats, related to those in the control group. In a volume conductor, the amplitude of the SNAP (a quadripole source) decreases in the inverse ratio of the cube of the distance between the nerve and the registry point ${ }^{23}$. Therefore, the smaller diameter of the tail, and consequently the shorter distance between the caudal nerve and the recording electrode in the diabetic rats, would result in larger SNAP amplitudes.

As we did not measure the diameter of the animal tails, 
these variations can be indirectly estimated by variations in the animal's weight. For any linear dimension of a body of any shape is proportional to the cubic root of its volume ${ }^{24}$. Because the weight of a body is proportional to its volume, the diameter of the rat's tail is proportional to the cubic root of the rat's weight. Our rats with diabetes lost weight during the experiment, whereas those in the control group gained weight. Thus, it is reasonable to suppose that the diameter of the tails, and consequently the distances between the caudal nerve and the recording electrodes, were significantly smaller in the diabetic rats than in the control rats. Authors that use needle type electrodes for recording ${ }^{2-6,12,14,15}$ did not observe this phenomenon and the amplitudes behaved as expected, probably because the recording electrode was always placed close to the nerve being studied, independently of the weight of the animal.

\section{Conclusion}

The nerve conduction in diabetic rats was slower whereas amplitudes of action potentials were larger then compared with normal rats.

\section{References}

1. Timperley WR, Boulton AJM, Davies-Jones GAB, Jarratt JA, Ward JD. Small vessel disease in progressive diabetic neuropathy associated with good metabolic control. J Clin Pathol. 1985;38:10308.

2. Brussee V, Cunningham A, Zochodne DW. Direct insulin signaling of reverses diabetic neuropathy. Diabetes. 2004;53:1824-30.

3. Drel VR, Mashtalir N, Ilnytska O, Shin J, Li F, Lyzogubov VV, Obrosova IG. The leptin-deficient (ob/ob) mouse: A new animal model of peripheral neuropathy of type 2 diabetes and obesity. Diabetes. 2006;55:3335-43.

4. Kennedy JM, Zochodne DW. Influence of experimental diabetes on the microcirculation of injured peripheral nerve: functional and morphological aspects. Diabetes. 2002;51:2233-40.

5. Kennedy JM, Zochodne DW. Experimental diabetic neuropathy with spontaneous recovery: Is there irreparable damage? Diabetes. 2005;54:830-7.

6. Obrosova IG, Li F, Abatan OI, Forsell MA, Komjáti K, Pacher P, Szabó C, Stevens MJ. Role of Poly (ADP-Ribose) Polymerase activation in diabetic neuropathy. Diabetes. 2004;53:711-20.

7. Prince AS, Agthong S, Middlemas AB, Tomlinson DR. Mitogenactivated protein kinase p38 mediates reduced nerve conduction velocity in experimental diabetic neuropathy. Diabetes. 2004;53:1851-6.

8. Snow LM, Sanchez AO, Mcloon LK, Serfass RC, Thompson LV. Effect of endurance exercise on myosin heavy chain isoform expression in diabetic rats with peripheral neuropathy. Am J Phys Med Rehabil. 2005;84:770-9.

9. King RHM. The role of glycation in the pathogenesis of diabetic polyneuropathy. J Clin Pathol Mol Pathol. 2001;54:400-8.

10. Cameron NE, Cotter MA, Robertson S. The effect of aldose reductase inhibition on the pattern of nerve conduction deficits in diabetic rats. Quarterly J Exp Physiol. 1989;74:917-26.

11. Cameron NE, Cotter MA. Neurovascular dysfunction in diabetic rats. J Clin Invest. 1995;96:1159-63.
12. Low PA, Schmelzer JD, Ward KK. The effect of age on energy metabolism and resistance to ischaemic conduction failure in rat peripheral nerve. J Physiol. 1986;374:263-71.

13. Schmelzer JD, Low PA. Electrophysiological studies on the effect of age on caudal nerve of the rat. Exp Neurol. 1987;96:612-20.

14. Coppey LJ, Davidson EP, Dunlap JA, Lund DD, Yorek MA. Slowing of motor nerve conduction velocity in streptozotocin-induced diabetic rats is preceded by impaired vasodilatation in arterioles that overlie the sciatic nerve. Int J Exp Diabetes Res. 2000;1:131-43.

15. Schratzberger P, Walter DH, Rittig K, Bahlmamm FH, Pola R, Curry C, Silver M, Krainin JG, Weinberg DH, Ropper AH, Isner JM. Reversal of experimental diabetic neuropathy by VEGF gene transfer. J Clin Invest. 2001;107(9):1083-92.

16. Feitosa MM, Larsson MHMA, Ushikoshi WS, Perri SHV. Determination of the motor nerve conduction velocity of the radial and ulnar nerves in clinically normal dogs. Arq Bras Med Vet Zootec. 2000;52(3):185-90.

17. Feitosa MM, Larsson MHMA, Ushikoshi WS, Perri SHV. Sensory nerve stimuli conduction evaluation standardization of tibial and peroneal nerves in healthy dogs using surface electrodes. Arq Bras Med Vet Zootec. 2002;54(2):127-32.

18. Kurokawa K, Almeida DF, Zhang Y, Hélbert CD, Page JG, Schweikart KM, Oh SJ. Sensory nerve conduction of the plantar nerve compared with other nerve conduction in rats. Clin Neurophys. 2004; $115: 1677-82$.

19. Maia JN, Carvalho CC, Galvão MH, Silva AL, Mendes ACG, Moraes SRA, Lins OG. Eletrophysiological study of the caudal nerve on developing rats. Acta Cir Bras. [serial on the Internet] 2010 Mar-Apr;25(2). Available from URL: http://www.scielo.br/acb

20. Miyoshi T, Goto I. Serial in vivo determinations of nerve conduction velocity in rat tails. Physiological and pathological changes. Electroenceph Clin Neurophysiol. 1973;35:125-31.

21. Leandri M, Saturno M, Cilli M, Bisaglia M, Lunardi G. Compound action potential of sensory tail nerves in the rat. Exp Neurol. 2006;203:148-57.

22. Zochodne DW, Nguyen C. Increased peripheral nerve microvessels in early experimental diabetics neuropathy: quantitative studies of nerve and dorsal root ganglia. J Neurol Sci. 1999;166:40-6.

23. Lagerlund TD. Volume conduction. In: Daube JR. Clinical Neurophysiology. Philadelphia: Davis Co; 1996. p.29-39.

24. Batschelet E. Introduction to mathematics for life sciences. SpringerVerlat Berlin: Heidelberg; 1971.

\section{Acknowledgments}

The authors wish to thank Professor Scott Heald for the review of the English language and for their cooperation in data collection for undergraduates Anderson Lima, Marina Hazin and Ana Carine Mendes.

Conflict of interest: none Financial source: none

\section{Correspondence:}

Celina Cordeiro de Carvalho.

Rua Rio Tejipió, 183/201

50721-640 Recife - PE Brasil

Phone: (55 81)9132-3733

celinacordeiro@hotmail.com
Received: September 21, 2010

Review: November 18, 2010

Accepted: December 20, 2010 